Magdalena Paluszkiewicz (10) https://orcid.org/0000-0002-7454-927X

Uniwersytet Łódzki

\title{
ZASIŁEK DLA BEZROBOTNYCH BYŁYCH FUNKCJONARIUSZY I ŻOŁNIERZY - WYBRANA PROBLEMATYKA PRAWNA NA TLE ORZECZNICTWA SĄDOWEGO
}

\begin{abstract}
Unemployment benefit for former officers of the uniformed services and soldiers selected legal issues in the context of court rulings
\end{abstract}

Although the unemployment benefit is a well-established institution in the Polish legal system, which makes it possible to mitigate the material consequences of unemployment, its practical functioning sometimes encounters serious difficulties, which is illustrated by the extensive court decisions regarding various aspects of the right of former officers of the uniformed services and soldiers to that benefit. The aim of the study is to show the more important problems of interpretation and to formulate proposals of their solution.

Słowa kluczowe: zasiłek dla bezrobotnych, funkcjonariusze, żołnierze, okres zasiłkowy, staż warunkujący nabycie zasiłku dla bezrobotnych, okresy karencji

Keywords: unemployment benefit, officer of the uniformed service, soldier, benefit period, service qualifying for unemployment benefit, withdrawal periods

ASJC: 3308, JEL: K31

\section{Uwagi wprowadzające}

Problematyka prawna zasiłku dla bezrobotnych jest w doktrynie prawa pracy kompleksowo i wyczerpująco przeanalizowana, o czym świadczą dość liczne opracowania o charakterze monograficznym i przyczynkarskim (Góral 2016, s. 796-875; Jaworska 2016; Paluszkiewicz 2018, s. 1121-1219), w których znalazł odzwierciedlenie również bogaty dorobek judykatury z tego zakresu. W kontekście prawa do tego świadczenia pewne pole do prowadzenia badań nadal pozostawia jednak uwzględnienie dość specyficznej - ze względu na charakter zatrudnienia - grupy osób na rynku pracy, jaką 
tworzą funkcjonariusze tak zwanych służb mundurowych oraz żołnierze. Stanowiąca podstawę regulacyjną w tym zakresie ustawa $\mathrm{z}$ dnia 20 kwietnia 2004 roku o promocji zatrudnienia i instytucjach rynku pracy (Dz.U. 2021, poz. 1100 tekst jedn. ze zm., dalej: „ustawa o promocji zatrudnienia”) zawiera unormowania, które w założeniu mają uwzględniać swoisty charakter niepracowniczego zatrudnienia administracyjnoprawnego tych osób, umożliwiając im nabywanie prawa do zasiłku dla bezrobotnych w sytuacji, w której utracili to zatrudnienie i nie ma dla nich odpowiedniej oferty pracy, pracy zastępczej czy innej formy pomocy. Dość obszerne orzecznictwo sądowe dotyczące zarysowanej problematyki świadczy jednak o tym, że zamierzenia ustawodawcy nie zawsze znajdują dostateczne odzwierciedlenie w praktyce. Celem opracowania jest więc zidentyfikowanie rozwiązań prawnych budzących najpoważniejsze wątpliwości interpretacyjne oraz nakreślenie kierunków ich niezbędnych zmian.

\section{Długość stażu warunkującego nabycie prawa do zasiłku dla bezrobotnych przez funkcjonariuszy i żołnierzy}

Jak wiadomo, zasiłek dla bezrobotnych jest świadczeniem pieniężnym przyznawanym osobom mającym status bezrobotnego, a jego nabycie uzależnione jest między innymi od określonej długości stażu (art. 71 ustawy o promocji zatrudnienia). Zasadniczo od wszystkich osób bezrobotnych, w tym od byłych funkcjonariuszy i żołnierzy, wymaga się wykazania co najmniej 365 dni stażu (na temat jego rodzaju w dalszej części opracowania) w pewnym okresie referencyjnym wynoszącym 18 miesięcy poprzedzających rejestrację (art. 71 ust. 2 pkt 1). W pewnych przypadkach jednak okres ten może być krótszy. Dotyczy to osób zwalnianych z zasadniczej służby wojskowej lub okresowej służby wojskowej. Wówczas prawo do zasiłku będzie przysługiwało w sytuacji, jeżeli okres odbywania służby wynosił co najmniej 240 dni i przypadał w okresie 18 miesięcy poprzedzających dzień zarejestrowania się w powiatowym urzędzie pracy (art. 71 ust. 4).

Na wyjątkowość tego ostatniego rozwiązania wskazują jeszcze co najmniej dwa elementy. Po pierwsze, funkcją art. 71 ust. 4 ustawy o promocji zatrudnienia jest uzależnienie prawa do zasiłku wyłącznie od okresu wskazanej w nim służby wojskowej, inaczej niż w art. 71 ust. 2 pkt 1, w którym okresy tej służby mogą być łączone jeszcze $\mathrm{z}$ innymi okresami zatrudnienia i okresami z nimi zrównanymi (uzasadnienie wyroku Wojewódzkiego Sądu Administracyjnego w Lublinie z dnia 7 grudnia 2006 roku, III SA/Lu 437/06, LEX nr 327463). Po drugie, o ile w przypadku stażu wynoszącego co najmniej 365 dni, powinien on przypadać w okresie poprzedzającym bezpośrednio (od 27 maja 2014 roku, zmiana wprowadzona ustawą z dnia 14 marca 2014 roku o zmianie ustawy o promocji zatrudnienia i instytucjach rynku pracy, Dz.U. 2014, poz. 598) dzień rejestracji we właściwym urzędzie pracy, o tyle takiego zastrzeżenia „bezpośredniości” dla okresu referencyjnego nie wprowadzono przy konieczności wykazania co najmniej 240 dni służby. Z jednej strony rozwiązanie takie nie motywuje danej osoby do niezwłocznej rejestracji w urzędzie pracy, z drugiej strony umożliwia uwzględnianie dużo 
szerszego zakresu czasu przed rejestracją, w którym może przypadać referencyjny okres 18 miesięcy, co - jak się wydaje - jest istotne w przypadkach, w których służby tej nie odbywano w sposób nieprzerwany ${ }^{1}$. Wprawdzie obowiązek odbywania zasadniczej służby wojskowej został zawieszony ${ }^{2}$ - w związku z dążeniem do uzawodowienia Sił Zbrojnych (Nowak 2019, s. 79), z kolei okresowa służba wojskowa ma raczej nadzwyczajny charakter, biorąc pod uwage przesłanki jej pełnienia (art. 108 ust. 1 ustawy o powszechnym obowiązku obrony) - jednak ustawodawca zostawił rozwiązania z nimi związane w ustawie, ponieważ potencjalnie nadal mogą zostać wykorzystane. Do tego czasu warto jednak zastanowić się nad ich kształtem, gdyż dotychczasowa praktyka ich stosowania wskazywała na występowanie poważnych problemów interpretacyjnych, zwłaszcza w kontekście zasadniczej służby wojskowej.

Służba ta nie jest pełniona zawodowo, ponieważ wiąże się z obowiązkowym przeszkoleniem wojskowym w nieprzerwanym okresie (Nowak 2019, s. 79). W świetle art. 56 ust. 1 ustawy o powszechnym obowiązku obrony jako równoznaczna ze spełnieniem obowiązku zasadniczej służby wojskowej traktowana jest służba w formacjach uzbrojonych niewchodzących w skład Sił Zbrojnych, takich jak Policja, Straż Graniczna czy Służba Ochrony Państwa (wcześniej w Biurze Ochrony Rządu; rozporządzenie Rady Ministrów z dnia 3 lutego 2011 roku w sprawie określenia formacji uzbrojonych niewchodzących w skład Sił Zbrojnych, w których pełnienie służby jest równoznaczne ze spełnieniem obowiązku zasadniczej służby wojskowej, Dz.U. 2011, nr 42, poz. 215). Na tle tych unormowań powstały więc wątpliwości, jakiej długości stażem powinny się legitymować osoby zwalniane ze służby kandydackiej w oddziałach prewencji Policji, żeby nabyć prawo do zasiłku dla bezrobotnych - 240 czy 365 dni. W judykaturze w kwestii tej zarysowały się dwa odrębne stanowiska. Zgodnie z pierwszym z nich, równoznaczne traktowanie służby w formacjach uzbrojonych niewchodzących w skład Sił Zbrojnych ze spełnieniem obowiązku zasadniczej służby wojskowej nie odnosi się do unormowań ustawy o promocji zatrudnienia, a jedynie do ustawy o powszechnym obowiązku obrony. Owa równoznaczność oznacza, że pełniąc służbę w formacjach uzbrojonych, osoba wypełniła obowiązek służby wojskowej tak samo, jak uczyniłaby to, pełniąc zasadniczą służbę wojskową. Służba w innych formacjach stanowi jednak odrębną od zasadniczej służby wojskowej instytucję prawną, pomimo że przez jej odbycie osoby zostają zwolnione z obowiązku odbycia zasadniczej służby wojskowej (uzasadnienie wyroku Wojewódzkiego Sądu Administracyjnego w Poznaniu z dnia 4 października 2007 roku, IV SA/Po 125/07, LEX nr 982803; uzasadnienie wyroku Wojewódzkiego Sądu Administracyjnego w Szczecinie z dnia 19 grudnia 2007 roku, II SA/Sz 734/07, LEX nr 470204). Dodatkowo przepis art. 71 ust. 4 ustawy o promocji

1 Art. 82 ust. 3 ustawy z dnia 21 listopada 1967 roku o powszechnym obowiązku obrony Rzeczypospolitej Polskiej (Dz.U. 2019, poz. 1541 tekst jedn. ze zm., dalej: „ustawa o powszechnym obowiązku obrony") przewidywał możliwość pełnienia zasadniczej służby wojskowej z przerwami.

2 Od 1 stycznia 2010 roku na mocy art. 21 ustawy z dnia 27 sierpnia 2009 roku o zmianie ustawy o powszechnym obowiązku obrony RP oraz zmianie niektórych innych ustaw (Dz.U. 2009, nr 161, poz. 1278). Instytucja ta może zostać ponownie wykorzystana w przypadku ogłoszenia mobilizacji lub w razie wojny. 
zatrudnienia, statuujący wymóg co najmniej 240 dni odbywania zasadniczej służby wojskowej, ma charakter lex specialis w stosunku do art. 71 ust. 1 pkt 2 tej ustawy, z którego wynika warunek wykazania co najmniej 365 dni okresu zatrudnienia. Ze względu na zasadę exceptiones non sunt extendendae, skoro w art. 71 ust. 4 nie ma mowy o służbie w formacjach uzbrojonych niewchodzących w skład Sił Zbrojnych, przepis ten do tych przypadków nie ma zastosowania. Co więcej, gdyby intencją ustawodawcy było przyznanie prawa do zasiłku po 240 dniach służby osobom zwolnionym ze służby kandydackiej w oddziale prewencji Policji lub innych rodzajach służby, na przykład takich, jak wymienione w art. 71 ust. 2 pkt 1, to wówczas albo odwołałby się do wyliczenia tych służb zawartego w omawianym przepisie, albo wprost by te służby wymienił. W rezultacie - ponieważ osoba w służbie kandydackiej w Policji, na gruncie przepisów ustawy dotyczącej tej formacji, pełni ją w charakterze funkcjonariusza - mają więc do niej zastosowanie przepisy art. 71 ust. 2 pkt 1 ustawy o promocji zatrudnienia i wymóg wykazania co najmniej 365 dni stażu warunkującego nabycie prawa do zasiłku dla bezrobotnych (uzasadnienie wyroku Wojewódzkiego Sądu Administracyjnego w Poznaniu z dnia 4 października 2007 roku, IV SA/Po 125/07, LEX nr 982803; uzasadnienie wyroku Wojewódzkiego Sądu Administracyjnego w Szczecinie z dnia 19 grudnia 2007 roku, II SA/Sz 734/07, LEX nr 470204).

Drugie stanowisko w judykaturze oparte zostało na wykładni teleologicznej i systemowej. Interpretując równoznaczność służby w innych formacjach z zasadniczą służbą wojskową, podniesiono, że oznacza ona konieczność ich utożsamiania. W konsekwencji powoduje to przyznanie osobom zwolnionym ze służby kandydackiej takich samych uprawnień jak osobom zwalnianym z zasadniczej służby wojskowej. Ponadto - odwołując się do założenia o racjonalności ustawodawcy - wskazano, że trudno przyjąć wykładnię pozbawiającą swoistego przywileju w nabywaniu świadczenia $\mathrm{z}$ tytułu bezrobocia te osoby, które odbyły służbę równoznaczną z wojskową. Skoro w przepisach wykonawczych ustawodawca wyznaczył krótszy niż 365 dni okres odbywania służby równoznacznej z wojskową, oznaczałoby to postawienie w dużo gorszej sytuacji osób, które ją odbywają, w porównaniu do sytuacji osób odbywających zasadniczą służbą wojskową. To z kolei stałoby w sprzeczności z konstytucyjną zasadą równości, nakazującą traktować w ten sam sposób osoby charakteryzujące się w tym samym stopniu cechą relewantną. W rezultacie wykładnia systemowa oraz celowościowa, nakazująca uwzględniać również podstawowe wartości i zasady konstytucyjne, prowadzą do wniosku, że pomimo literalnego brzmienia art. 71 ust. 4 ustawy o promocji zatrudnienia, ma on zastosowanie również do osób, które odbyły służbę w formacjach uzbrojonych niewchodzących w skład Sił Zbrojnych (uzasadnienie wyroku Wojewódzkiego Sądu Administracyjnego w Lublinie z dnia 7 grudnia 2006 roku, III SA/Lu 437/06, LEX nr 327463; uzasadnienie wyroku Naczelnego Sądu Administracyjnego z dnia 17 lutego 2009 roku, I OSK 389/09, LEX nr 522425).

Nie wchodząc w szersze rozważania, należy stwierdzić, że bardziej przekonujące jest pierwsze stanowisko, ponieważ sytuacja faktyczna osób w służbie kandydackiej nie była taka sama jak sytuacja osób pełniących zasadniczą służbę wojskową. W szczególności ci pierwsi, mając status funkcjonariusza, otrzymywali uposażenie, natomiast osoby, 
które pełniły zasadniczą służbę wojskową, oprócz żołdu nie otrzymywały żadnego wynagrodzenia ani uposażenia. Jako odzwierciedlenie ich zróżnicowanego położenia można odczytywać również dyferencjację uprawnień żołnierzy i osób spełniających zastępczo obowiązek służby wojskowej oraz członków ich rodzin w wydanym na podstawie ustawy o powszechnym obowiązku obrony rozporządzeniu (rozporządzenie Rady Ministrów z dnia 5 listopada 1992 roku w sprawie szczególnych uprawnień żołnierzy i osób spełniających zastępczo obowiązek służby wojskowej oraz członków ich rodzin, Dz.U. 1992, nr 85, poz. 430 ze zm.), które obowiązywało do 2007 roku. Pomimo że pełnienie służby w formacji uzbrojonej niewchodzącej w skład Sił Zbrojnych Rzeczypospolitej Polskiej, takiej jak oddział prewencji Policji, było równoznaczne ze spełnieniem obowiązku odbycia zasadniczej służby wojskowej, w rezultacie nie było jednak równoznaczne z korzystaniem ze wszystkich uprawnień, jakie przysługiwały żołnierzom odbywającym zasadniczą służbę wojskową (uzasadnienie wyroku Naczelnego Sądu Administracyjnego (do 31 grudnia 2003 roku) w Białymstoku z dnia 20 czerwca 2002 roku, SA/Bk 209/02, LEX nr 79657). Słabsza pozycja socjalna osób pełniących zasadniczą służbę wojskową stanowiła więc również uzasadnienie dla ustanowienia bardziej liberalnych zasad dostępu do zasiłku dla bezrobotnych w sytuacji braku propozycji odpowiedniej pracy lub pracy zastępczej.

\section{Rodzaj stażu warunkującego nabycie prawa do zasiłku dla bezrobotnych przez funkcjonariuszy i żołnierzy}

Wymagany przez ustawodawcę staż do nabycia prawa do zasiłku dla bezrobotnych może składać się z dwóch rodzajów okresów, obejmujących różne formy aktywności zarobkowej (art. 71 ust. 1 pkt 2) oraz okresy z nimi zrównane (art. 71 ust. 2). Należy przy tym podkreślić, że regulacja zawarta w art. 71 ustawy o promocji zatrudnienia ma charakter ściśle bezwzględnie obowiązujący, co wyklucza uznanie administracyjne i uniemożliwia uwzględnienie innych niż enumeratywnie wskazane okresów jako zrównanych z okresami zatrudnienia przy ustalaniu prawa do zasiłku dla bezrobotnych. W tym kontekście należy spróbować odpowiedzieć na pytanie, które z tych okresów mają znaczenie przy nabywaniu prawa do tego świadczenia przez zwolnionych ze służby funkcjonariuszy i żołnierzy.

Generalną zasadą jest, że do okresu warunkującego nabycie prawa do zasiłku dla bezrobotnych zalicza się zatrudnienie wykonywane w zamian za co najmniej minimalne wynagrodzenie za pracę, od którego istnieje obowiązek opłacania składki na Fundusz Pracy (art. 71 ust. 1 pkt 2). Z punktu widzenia analizowanej tu problematyki istotne znaczenie ma sposób rozumienia samego zatrudnienia. Zgodnie z definicją zawartą w słowniczku ustawy (art. 2 ust. 1 pkt 43), obok stosunku pracy i umowy o pracę nakładczą, obejmuje ono właśnie stosunki służbowe. Istotne wątpliwości wynikają jednak z braku zdefiniowania pojęcia „stosunków służbowych” w ustawie o promocji zatrudnienia, co może wywoływać trudności w ustalaniu uprawnień zasiłkowych. W tym 
kontekście warto zwrócić uwagę na już wspomniany wymóg opłacania składek na Fundusz Pracy, który z kolei jest skorelowany z podleganiem obowiązkowym ubezpieczeniom emerytalno-rentowym. Należy podkreślić, że takim ubezpieczeniom, obok osób odbywających służbę zastępczą, podlegali do końca 2018 roku wyłącznie funkcjonariusze Służby Celnej ${ }^{3}$, a po tej dacie zostali objęci systemem zaopatrzenia społecznego jako funkcjonariusze Służby Celno-Skarbowej (ustawa z dnia 11 maja 2017 roku o zmianie ustawy o zaopatrzeniu emerytalnym funkcjonariuszy Policji, Agencji Bezpieczeństwa Wewnętrznego, Agencji Wywiadu, Służby Kontrwywiadu Wojskowego, Służby Wywiadu Wojskowego, Centralnego Biura Antykorupcyjnego, Straży Granicznej, Biura Ochrony Rządu, Państwowej Straży Pożarnej i Służby Więziennej oraz ich rodzin oraz niektórych innych ustaw, Dz.U. 2017, poz. 1321). Z tego względu obowiązek opłacania składek na Fundusz Pracy za osoby pozostające w stosunku służbowym dotyczył również innych niż pracodawcy jednostek organizacyjnych (art. 104 ust. 1 pkt 1 lit. a ustawy o promocji zatrudnienia). W konsekwencji takiego rozumowania można przyjąć, że stosunek służbowy funkcjonariuszy Służby Celnej jako okres warunkujący nabycie prawa do zasiłku mieścił się w dyspozycji art. 71 ust. 2 pkt 1 ustawy.

Zaproponowany sposób interpretacji nie rozwiewa jednak wszystkich wątpliwości, ponieważ w art. 71 ust. 1 pkt 2 lit. i ustawy o promocji zatrudnienia obok zatrudnienia wymieniono „pełnienie służby”. W związku z powyższym, skoro stosunki służbowe wchodzą, zgodnie z definicją ustawową, w zakres pojęcia „zatrudnienie”, to „pełnienie służby” nie powinno być utożsamiane $\mathrm{z}$ pozostawaniem $\mathrm{w}$ stosunku służbowym. Pełnienie służby może zostać uwzględnione przy ustalaniu prawa do zasiłku, o ile od uzyskiwanego z niej dochodu lub wynagrodzenia istnieje obowiązek opłacania składki na Fundusz Pracy.W tym przypadku nie ma jednak wymogu, by składka była opłacona od dochodu w wysokości co najmniej minimalnego wynagrodzenia za pracę. Jak wspomniano, ubezpieczeniom emerytalno-rentowym podlegają obowiązkowo również osoby odbywające służbę zastępczą (na podstawie art. 6 ust. 1 pkt 12 ustawy z dnia 13 października 1998 roku o systemie ubezpieczeń społecznych, Dz.U. 2021, poz. 423 tekst jedn. ze zm., dalej: „ustawa systemowa”) i również w ich przypadku istnieje obowiązek opłacania składek na Fundusz Pracy (na podstawie art. 104 ust. 1 pkt 3 lit. f ustawy o promocji zatrudnienia). W czasie pełnienia służby osoby te jednak nie pozostają w stosunku pracy z podmiotem, do którego zostały skierowane. Otrzymują również świadczenie w wysokości niższej niż minimalne wynagrodzenie za pracę (art. 23 ust. $1 \mathrm{w}$ zw. $\mathrm{z}$ art. 26 ust. 1 pkt 2 ustawy z dnia 28 listopada 2003 roku o służbie zastępczej, Dz.U. 2018, poz. 855 tekst jedn.).W związku z poczynionymi rozważaniami należy zaproponować wykładnię, w myśl której stosunek służbowy, jako wymieniony w ustawowej definicji zatrudnienia obok stosunku pracy i umowy o pracę nakładczą, należy identyfikować z relacją prawną realizowaną w celu zarobkowym. Pełnienie służby obejmuje zaś stosunki organizacyjnoprawne służące

3 Pomijam kwestię funkcjonariuszy innych służb i żołnierzy zawodowych, którzy podlegali pod powszechny system ubezpieczeń społecznych w okresie od początku 1999 roku do października 2003 roku, czyli jeszcze przed wejściem w życie ustawy o promocji zatrudnienia. 
zasadniczo innym niż zarobkowe celom na tle realizacji powszechnego obowiązku obrony Rzeczypospolitej Polskiej.

Pojęcia służby i stosunków służbowych zostały również użyte na gruncie art. 71 ust. 2 ustawy o promocji zatrudnienia, który odnosi się do tych okresów zaliczanych do stażu zasiłkowego, traktowanych jako zrównane z zatrudnieniem. W art. 71 ust. 2 pkt 5 mowa jest o okresach, za które przyznano odszkodowanie z tytułu niezgodnego z przepisami rozwiązania przez pracodawcę stosunku służbowego. Z kolei w art. 71 ust. 2 pkt 3 ponownie użyto określenia „służba”, odsyłając w zakresie sposobu jej rozumienia do pkt 1 ust. 2, zawierającego enumeratywne wyliczenie jej rodzajów. Oprócz służby $\mathrm{w}$ charakterze funkcjonariusza konkretnych formacji wymieniono w nim również na przykład kontraktową służbę wojskową, które łącznie można kwalifikować jako stosunki służbowe, jak również zasadniczą służbę wojskową, przeszkolenie wojskowe czy ćwiczenia wojskowe, mające związek z realizacją powszechnego obowiązku obrony Rzeczypospolitej Polskiej. Na gruncie analizy art. 71 ust. 2 można więc dojść do nieco innego niż wcześniej wniosku, zgodnie z którym pełnienie służby jest pojęciem szerszym, obejmującym również stosunki służbowe. Z porównania pierwszych dwóch ustępów art. 71 ustawy wynika jednak, że w ust. 1 mowa o służbie/stosunkach służbowych związanych z opłacaniem składek na Fundusz Pracy (odbywanie zastępczej służby wojskowej, stosunek służbowy funkcjonariuszy celnych), zaś w ust. 2 - o służbie/ stosunkach służbowych pozostałych funkcjonariuszy i żołnierzy, z którą nie wiązał się obowiązek opłacania składki na Fundusz Pracy.

Aktualnie zarówno funkcjonariusze, jak i żołnierze nie są objęci obowiązkiem ubezpieczeń społecznych w okresie pełnienia służby ${ }^{4}$, a zatem w trakcie realizacji stosunku służbowego nie ma również obowiązku opłacania składki na Fundusz Pracy. Dopiero w przypadku, w którym następuje zwolnienie ze służby funkcjonariusza lub żołnierza, który dodatkowo nie spełnia warunków do nabycia renty lub emerytury z odrębnego dla tych służb systemu zaopatrzenia, dla płatnika aktualizuje się obowiązek przekazania składek na wspomniane rodzaje ubezpieczeń społecznych ${ }^{5}$ oraz składek na Fundusz Pracy

4 Objęci są systemem zaopatrzenia emerytalnego, który tworzą zasadniczo dwie ustawy: ustawa z dnia 10 grudnia 1993 roku o zaopatrzeniu emerytalnym żołnierzy zawodowych oraz ich rodzin (Dz.U. 2020, poz. 586 tekst jedn. ze zm.) oraz ustawa z dnia 18 lutego 1994 roku o zaopatrzeniu emerytalnym funkcjonariuszy Policji, Agencji Bezpieczeństwa Wewnętrznego, Agencji Wywiadu, Służby Kontrwywiadu Wojskowego, Służby Wywiadu Wojskowego, Centralnego Biura Antykorupcyjnego, Straży Granicznej, Straży Marszałkowskiej, Służby Ochrony Państwa, Państwowej Straży Pożarnej, Służby Celno-Skarbowej i Służby Więziennej oraz ich rodzin (Dz.U. 2020, poz. 723 tekst jedn.), zachowują również prawo do uposażenia w czasie choroby i macierzyństwa na podstawie pragmatyk służbowych.

5 Art. 6a ustawy z dnia 10 grudnia 1993 roku o zaopatrzeniu emerytalnym żołnierzy zawodowych oraz ich rodzin, Dz.U. 2020, poz. 586 tekst jedn. ze zm.; art. 69a ustawy z dnia 6 kwietnia 1990 roku o Policji, Dz.U. 2020, poz. 360 tekst jedn. ze zm.; art. 60a ustawy z dnia 24 sierpnia 1991 roku o Państwowej Straży Pożarnej, Dz.U. 2020, poz. 1123 tekst jedn. ze zm.; art. 74a ustawy z dnia 12 października 1990 roku o Straży Granicznej, Dz.U. 2020, poz. 305 tekst jedn. ze zm.; art. 168 ustawy z dnia 9 kwietnia 2010 roku o Służbie Więziennej, Dz.U. 2020, poz. 848 tekst jedn. ze zm.; art. 92a ustawy z dnia 24 maja 2002 roku o Agencji Bezpieczeństwa Wewnętrznego oraz Agencji Wywiadu, Dz.U. 2020, poz. 27 tekst jedn. ze zm.; art. 52 ustawy 
(art. 104 ust. 1 pkt 1 lit. g i h ustawy o promocji zatrudnienia; w tym drugim przypadku funkcjonariusz ma wybór - czy chce pobierać rentę, czy też chce, by składki przekazać do ZUS i na Fundusz Pracy). Jednak nawet w omawianym przypadku opłacenie składek na Fundusz Pracy po ustaniu stosunku służbowego nie uzasadnia zaliczania okresów pełnienia służby do okresów zatrudnienia, o których mowa w art. 71 ust. 1, ponieważ okresy te zostały przez ustawodawcę zaliczone do grupy tak zwanych okresów zrównanych na podstawie art. 71 ust. 2 pkt 1 ustawy o promocji zatrudnienia.

Wśród okresów zrównanych, uwzględnianych w stażu uprawniającym do nabycia prawa do zasiłku w przypadku byłych funkcjonariuszy lub żołnierzy, są również okresy pobierania różnego rodzaju świadczeń socjalnych (art. 71 ust. 2 pkt 3). Zauważyć przy tym należy, że ustawodawca wskazał wyłącznie okres pobierania renty z tytułu niezdolności do służby jako okres zrównany; takiego wyraźnego odniesienia do służby ani do stosunku służbowego nie ma natomiast w przypadku pozostałych, wymienionych w tym przepisie okresów pobierania świadczeń, $\mathrm{w}$ tym również przypadających po ustaniu zatrudnienia. Na szczególną uwagę zasługują świadczenia przysługujące w okresie choroby przypadającej po ustaniu zatrudnienia, ponieważ zapewniają one źródło utrzymania osobie, która nie spełnia warunku zdolności do podjęcia pracy, wobec czego nie uzyska statusu bezrobotnego ani uzależnionego od niego prawa do zasiłku dla bezrobotnych. Uwzględnianie okresu pobierania tych świadczeń w stażu zasiłkowym ma również zapobiegać przypadkom, w których spełnienie warunku wymaganego stażu do nabycia prawa do tego świadczenia (co najmniej 365 dni w okresie 18 miesięcy bezpośrednio poprzedzających rejestrację) nie będzie możliwe właśnie ze względu na przedłużającą się chorobę.

W tym kontekście na szczególną uwagę zasługuje problematyka prawa do świadczeń z tytułu choroby po ustaniu stosunku służbowego funkcjonariuszy służby celnej i możliwości wliczania okresów ich pobierania na podstawie art. 71 ust. 2 pkt 3 do stażu warunkującego nabycie prawa do zasiłku dla bezrobotnych. Wspomniani funkcjonariusze podlegali obowiązkowo ubezpieczeniu emerytalno-rentowemu i wypadkowemu (na podstawie nieobowiązującego już art. 6 ust. 1 pkt 18a oraz art. 12 ustawy systemowej; szerzej o przyczynach pozostawienia tych funkcjonariuszy w powszechnym systemie ubezpieczeń społecznych zob. na przykład Antonów 2004, s. 105-106), nie zostali natomiast objęci ubezpieczeniem chorobowym, ponieważ w czasie choroby przysługiwało im uposażenie (art. 152 ustawy z dnia 27 sierpnia 2009 roku o Służbie Celnej, Dz.U. 2009, nr 168, poz. 1323 ze zm., dalej: „ustawa o Służbie Celnej”). Zgodnie ze stanowiskiem wyrażonym w orzecznictwie sądów administracyjnych w ustawowym katalogu w art. 71 ust. 2 pkt 3 nie wymieniono okresu pobierania przez byłego

z dnia 9 czerwca 2006 roku o służbie funkcjonariuszy Służby Kontrwywiadu Wojskowego oraz Służby Wywiadu Wojskowego, Dz.U. 2020, poz. 1221 tekst jedn. ze zm.; art. 80 ustawy z dnia 9 czerwca 2006 roku o Centralnym Biurze Antykorupcyjnym, Dz.U. 2019, poz. 1921 tekst jedn. ze zm.; art. 250a ustawy z dnia 16 listopada 2016 roku o Krajowej Administracji Skarbowej, Dz.U. 2020, poz. 505 tekst jedn. ze zm.; art. 147 ustawy z dnia 8 grudnia 2017 roku o Służbie Ochrony Państwa, Dz.U. 2020, poz. 384 tekst jedn. ze zm., art. 56 ustawy z dnia 26 stycznia 2018 roku o Straży Marszałkowskiej, Dz.U. 2019, poz. 1940 tekst jedn. ze zm. 
funkcjonariusza celnego uposażenia chorobowego po ustaniu służby. Ponadto sam okres niezdolności do pracy z powodu choroby nie podlegał zaliczeniu do okresu warunkującego nabycie prawa do zasiłku dla bezrobotnych, ponieważ w przepisie wyraźnie stanowi się o pobieraniu z tego tytułu świadczeń (wyrok Wojewódzkiego Sądu Administracyjnego w Gdańsku z dnia 25 lipca 2019 roku, III SA/Gd 352/19, LEX nr 2704720, a także wyrok Wojewódzkiego Sądu Administracyjnego w Krakowie z dnia 9 października 2018 roku, III SA/Kr 779/18, LEX nr 2579435). W tym kontekście istotne ustalenia w odniesieniu do funkcjonariuszy celnych zostały poczynione w oderwaniu od wykładni językowej w orzecznictwie sądów powszechnych.

Sąd Najwyższy w jednym z wyroków wskazał, że chociaż sytuacja celnika, który stał się niezdolny do służby przed jej zakończeniem i pozostaje nadal do niej niezdolny z tej samej przyczyny po jej ustaniu, nie została uregulowana w ustawie o Służbie Celnej, to jednak pragmatyki służbowe nie powinny normować kwestii świadczeń z tytułu choroby poniżej standardu wyznaczonego przez ustawę z dnia 25 czerwca 1999 roku o świadczeniach pieniężnych $\mathrm{z}$ ubezpieczenia społecznego w razie choroby i macierzyństwa („w brzmieniu według tekstu jedn. Dz.U. 2010, nr 77, poz. 512 ze zm.”).W ocenie Sądu Najwyższego szczególne unormowanie sytuacji ubezpieczeniowej funkcjonariuszy celnych, podlegających w pewnym okresie powszechnemu systemowi ubezpieczeń społecznych, umożliwiało porównanie ich sytuacji prawnej do pozostałych osób podlegających obowiązkowemu ubezpieczeniu emerytalnemu, rentowym i wypadkowemu. Zasiłek chorobowy po ustaniu tytułu ubezpieczenia jest bowiem szczególnym świadczeniem gwarancyjnym, niezależnym od opłacenia składek na to ubezpieczenie, toteż zdaniem tego sądu konieczne było rozważenie, czy dopuszczalna jest wykładnia, zgodnie z którą funkcjonariusz Służby Celnej może nabyć prawo do zasiłku chorobowego po zakończeniu służby, jeżeli niezdolność do jej wykonywania powstała w okresie przed jej zakończeniem, nie doszło do przekroczenia okresu zasiłkowego i nie wystąpiły okoliczności wyłączające prawo do tego zasiłku (uzasadnienie wyroku Sądu Najwyższego z dnia 18 października 2013 roku, I UK 125/13, OSNP 2014/9/137).

Na skutek tych rozważań Sądu Najwyższego, przeprowadzonych w postępowaniu kasacyjnym, sąd ponownie rozpoznający sprawę odstąpił od wykładni językowej i zastosował wykładnię systemową, przyznając prawo do zasiłku chorobowego, gdyż uznał, że były funkcjonariusz służby celnej znalazł się w oczywiście mniej korzystnej sytuacji prawnej w stosunku do pozostałych podmiotów podlegających na podstawie ustawy systemowej ubezpieczeniu chorobowemu (co oznaczało naruszenie art. 2a ustawy systemowej, stanowiącej rozwinięcie art. 32 Konstytucji RP) i otrzymujących świadczenie z tytułu niezdolności do pracy również po ustaniu ubezpieczenia, co stanowiło naruszenie art. 67 Konstytucji RP (wyrok Sądu Okręgowego w Krakowie z dnia 7 kwietnia 2014 roku, VII Ua 110/13, LEX nr 2440903; wyrok Sądu Okręgowego Warszawa-Praga w Warszawie z dnia 28 marca 2019 roku, VII Ua 2/19, LEX nr 2675893) w związku z jej art. 32. Uwzględnienie zasad równego traktowania przy wykładni systemowej stosowanej wobec funkcjonariuszy celnych spowodowało więc, że nie była ona surowsza niż wykładnia dotycząca innych osób podlegających obowiązkowo ubezpieczeniom społecznym 
i umożliwiała przyznanie zasiłku chorobowego po ustaniu stosunku służbowego, którego czas pobierania podlegał wliczeniu do okresu warunkującego nabycie prawa do zasiłku dla bezrobotnych na podstawie art. 71 ust. 2 pkt 3 ustawy o promocji zatrudnienia.

$\mathrm{W}$ sferze zabezpieczenia społecznego nie ma natomiast tak istotnych podobieństw między ubezpieczonymi w powszechnym systemie a innymi niż celnicy funkcjonariuszami. Dlatego z chwilą zwolnienia policjanta ze służby nie ma do niego zastosowania ustawa zasiłkowa. Skoro bowiem ustawodawca uregulował w art. 69a ustawy z dnia 6 kwietnia 1990 roku o Policji (Dz.U. 2020, poz. 360 tekst jedn. ze zm., dalej: „ustawa o Policji”) konieczność przekazania do ZUS składek na ubezpieczenie emerytalno-rentowe i nie odniósł się do składek na ubezpieczenie chorobowe, nie można przyjąć, że policjant po zwolnieniu ze służby ma prawo do zasiłku chorobowego (wyrok Sądu Najwyższego z dnia 19 stycznia 2017 roku, I UK 121/16, LEX nr 2216098). Funkcjonariusze Policji, którzy są niezdolni do podjęcia zatrudnienia po zwolnieniu ze służby, zachowują prawo do uposażenia przez ustawowo określony czas. Okres jego pobierania nie został jednak zamieszczony w katalogu okresów zrównanych, które można uwzględniać w stażu warunkującym nabycie prawa do zasiłku dla bezrobotnych ${ }^{6}$.

Podsumowując dotychczasowe rozważania, należy stwierdzić, że w aktualnym stanie prawnym przy nabywaniu prawa do zasiłku dla bezrobotnych dla funkcjonariuszy i żołnierzy zasadnicze znaczenie mają okresy wymienione w art. 71 ust. 2 ustawy (służby, odszkodowania za niezgodne z prawem rozwiązanie stosunku służbowego oraz pobierania renty z tytułu niezdolności do służby), natomiast do niedawna nieco inaczej pod tym względem kształtowały się zasady nabywania prawa do zasiłku dla bezrobotnych przez zwolnionych ze służby funkcjonariuszy Służby Celnej. Do okresów warunkujących nabycie prawa do zasiłku w ich przypadku ustawodawca zaliczył służbę związaną z obowiązkiem opłacania składek na Fundusz Pracy, jak również, w wyniku określonej linii orzeczniczej, możliwe było zaliczanie okresów pobierania zasiłku chorobowego po ustaniu stosunku służbowego. Po objęciu ich systemem zaopatrzenia społecznego na analogicznych zasadach do pozostałych funkcjonariuszy taki zabieg nie będzie już miał podstaw prawnych. Należy jeszcze wspomnieć, że wszystkie wymienione wyżej okresy mogą być ze sobą sumowane, bez względu na przerwy, które między nimi wystąpiły, z zastrzeżeniem, że przypadają w określonym czasie przed rejestracją (Paluszkiewicz 2018, s. 1194). Okresy zrównane mogą przy tym stanowić samodzielną podstawę do nabycia prawa do zasiłku dla bezrobotnych pod warunkiem wykazania ich odpowiedniej długości w wyznaczonym przez ustawodawcę

6 Art. 117 ust. 3 ustawy z dnia 6 kwietnia 1990 roku o Policji, Dz.U. 2020, poz. 360 tekst jedn. ze zm.; art. 101 ust. 3 ustawy z dnia 24 sierpnia 1991 roku o Państwowej Straży Pożarnej, Dz.U. 2020, poz. 1123 tekst jedn. ze zm.; art. 132 ust. 3 ustawy z dnia 24 maja 2002 roku o Agencji Bezpieczeństwa Wewnętrznego oraz Agencji Wywiadu, Dz.U.2020, poz. 27 tekst jedn. ze zm.; art. 121 ust. 3 ustawy z dnia 12 października 1990 roku o Straży Granicznej, Dz.U. 2020, poz. 305 tekst jedn. ze zm.; art. 99 ust. 3 ustawy o z dnia 9 czerwca 2006 roku o Centralnym Biurze Antykorupcyjnym, Dz.U.2019, poz. 1921 tekst jedn. ze zm.; art. 92 ust. 3 ustawy dnia 9 czerwca 2006 roku o służbie funkcjonariuszy Służby Kontrwywiadu Wojskowego oraz Służby Wywiadu Wojskowego, Dz.U.2020, poz. 1221 tekst jedn. ze zm.; art. 188 ust. 1 pkt 1 ustawy z dnia 8 grudnia 2017 roku o Służbie Ochrony Państwa, Dz.U. 2020, poz. 384 tekst jedn. ze zm. 
okresie referencyjnym (wyrok Wojewódzkiego Sądu Administracyjnego w Warszawie z dnia 22 sierpnia 2006 roku, II SA/Wa 938/06, LEX nr 282423; wyrok Wojewódzkiego Sądu Administracyjnego w Krakowie z dnia 20 czerwca 2012 roku, III SA/Kr 1547/11, LEX nr 1246005; wyrok Wojewódzkiego Sądu Administracyjnego w Krakowie z dnia 27 lutego 2013 roku, III SA/Kr 1354/12, LEX nr 1278042).

\section{Wpływ sposobu ustania stosunku służbowego na prawo do zasiłku dla bezrobotnych}

W art. 75 ustawy o promocji zatrudnienia ustawodawca określił katalog zróżnicowanych rodzajowo okoliczności, w których prawo do zasiłku nie przysługuje osobie bezrobotnej, mimo spełnienia określonych w art. 71 pozytywnych przesłanek jego nabycia. Spośród nich na szczególną uwagę zasługują przypadki związane z takimi sposobami zakończenia zatrudnienia, które wskazują na dobrowolny charakter bezrobocia i z tych względów nie zasługują na ochronę prawną. W orzecznictwie podkreśla się wyraźnie sankcyjny charakter tego rodzaju rozwiązań (wyrok Wojewódzkiego Sądu Administracyjnego w Łodzi z dnia 29 października 2013 roku, III SA/Łd 938/13, LEX nr 1504317; wyrok Wojewódzkiego Sądu Administracyjnego we Wrocławiu z dnia 17 sierpnia 2017 roku, IV SA/Wr 182/17, LEX nr 2349712; wyrok Wojewódzkiego Sądu Administracyjnego w Bydgoszczy z dnia 2 października 2018 roku, II SA/Bd 870/18, LEX nr 2579468), ponieważ w wyniku ich zastosowania okres zasiłkowy zostaje skrócony, a gdy okres karencyjny pokryje się w całości z okresem zasiłkowym, osoba bezrobotna wcale nie otrzyma świadczenia. Do tego rodzaju okoliczności powodujących konieczność zastosowania okresu karencji w wypłacie zasiłku, wynoszącego odpowiednio 90 i 180 dni, zalicza się, po pierwsze, rozwiązanie przez bezrobotnego stosunku pracy lub stosunku służbowego za wypowiedzeniem albo na mocy porozumienia stron, chyba że porozumienie stron nastąpiło z powodu upadłości, likwidacji pracodawcy lub zmniejszenia zatrudnienia z przyczyn dotyczących zakładu pracy albo rozwiązanie stosunku pracy lub stosunku służbowego za wypowiedzeniem lub na mocy porozumienia stron nastąpiło z powodu zmiany miejsca zamieszkania (art. 75 ust. 1 pkt 2), oraz, po drugie, spowodowanie przez bezrobotnego rozwiązania ze swej winy stosunku pracy lub stosunku służbowego bez wypowiedzenia (75 ust. 1 pkt 3). Nadmienić przy tym należy, że okoliczności te mają wpływ na prawo do zasiłku, o ile nastąpiły w okresie 6 miesięcy poprzedzających dzień rejestracji w urzędzie pracy w charakterze bezrobotnego.

W pierwszej kolejności należy zwrócić uwagę na sposób sformułowania przytoczonych przepisów, silnie inspirowany terminologią prawną występującą w kontekście zakończenia realizacji stosunków pracy, ale już niekoniecznie w przypadku ustania stosunków służbowych. Rozwiązanie tych ostatnich następuje bowiem zawsze w wyniku wydania przez upoważniony podmiot jednostronnego aktu o zwolnieniu ze służby (decyzji/ rozkazu personalnego), mającego charakter konstytutywny, bez względu na to, która strona zainicjowała jego zakończenie (Mazurczak-Jasińska 2015, s. 479). Nawet jeśli stroną 
inicjującą rozwiązanie stosunku służbowego jest funkcjonariusz/żołnierz zawodowy, jego czynność nie może być kwalifikowana tak, jak prawo kształtujące oświadczenie woli o wypowiedzeniu czy oferta zawarcia porozumienia rozwiązującego. Między stronami stosunku służbowego nie ma bowiem możliwości zawarcia porozumienia, którego skutkiem byłoby jego ustanie (Mazurczak-Jasińska 2015, s. 479). W przypadku żołnierzy zawodowych ustawodawca wprawdzie przewidział explicite możliwość rozwiązywania stosunku służbowego za złożonym przez nich wypowiedzeniem, jednak skutek ten nastąpi dopiero jako konsekwencja wydanej przez właściwego przełożonego decyzji, w której określi on dokładny termin zwolnienia ze służby (art. 111 pkt 9 lit. a w zw. $z$ art. 115 ust. 1 ustawy z dnia 11 września 2003 roku o służbie wojskowej żołnierzy zawodowych Dz.U. 2021, poz. 1131 tekst jedn. ze zm.). Z kolei w przypadku Służby Więziennej są wskazane przypadki wygaśnięcia stosunku służbowego, które w innych pragmatykach zostały zakwalifikowane jako przyczyna rozwiązania stosunku służbowego ${ }^{7}$. W pragmatyce dotyczącej żołnierzy zawodowych natomiast ustawodawca określił przypadki ustania stosunku służbowego z mocy prawa (zob. art. 115 ust. 2 ustawy o służbie wojskowej żołnierzy zawodowych), podczas gdy ustawa o promocji zatrudnienia takiego sposobu ustania stosunku służbowego nie przewiduje.

Powyższe rozważania prowadzą do wniosku, że rozstrzygające znaczenie dla zasadności zastosowania okresu karencji przez organ zatrudnienia ustalający prawo do zasiłku powinna mieć materialnoprawna przyczyna rozwiązania stosunku służbowego, określona na podstawie treści aktu zwalniającego ze służby, ze szczególnym uwzględnieniem jego podstawy prawnej oraz uzasadnienia prawnego i faktycznego, jak również na podstawie świadectwa służby (na przykład $\$ 22$ rozporządzenia Ministra Spraw Wewnętrznych z dnia 14 maja 2013 roku w sprawie szczegółowych praw i obowiązków oraz przebiegu służby policjantów, Dz.U. 2020, poz. 1113 tekst jedn.). Jak się wydaje, w tym samym kierunku zmierza pogląd wyrażony w orzecznictwie, w kontekście art. 75 ust. 1 pkt 3 ustawy o promocji zatrudnienia, który to przepis nie zawiera odesłania w kwestii rozwiązania stosunku pracy i stosunku służbowego $\mathrm{z}$ winy bezrobotnego do Kodeksu pracy (ustawa z dnia 26 czerwca 1974 roku - Kodeks pracy, Dz.U.2020, poz. 1320 tekst jedn., dalej: „,Kodeks pracy”, ,k.p.”) ani do ustaw regulujących rozwiązanie stosunku służbowego. Dlatego każdorazowo sytuację bezrobotnego, którego pozbawiono prawa do zasiłku na podstawie przywołanego przepisu należy rozpatrywać indywidualnie, w zależności od tego, jakie przepisy regulują kwestię jego zatrudnienia (wyrok Wojewódzkiego Sądu Administracyjnego w Szczecinie z dnia 5 października 2017 roku, II SA/Sz 852/17, LEX nr 2390442). W praktyce nie jest to jednak zadanie łatwe, na co wskazują liczne przykłady z orzecznictwa, dotyczące zwłaszcza stosowania okresów karencyjnych w przypadku zawinionego przez byłego funkcjonariusza rozwiązania stosunku służbowego.

7 Na przykład orzeczenie przez komisję lekarską całkowitej niezdolności do służby czy prawomocne orzeczenie o wymierzeniu kary dyscyplinarnej wydalenia ze służby (zob. art. 97 ustawy o Służbie Więziennej). 
Jako spowodowanie w sposób zawiniony rozwiązania stosunku służbowego zostało na przykład potraktowane obligatoryjne zwolnienie ze służby funkcjonariusza Służby Celnej z powodu wniesienia przeciw niemu oskarżenia o przestępstwo umyślne, ścigane z oskarżenia publicznego (na podstawie art. 25 ust. 1 pkt 8a ustawy z dnia 24 lipca 1999 roku o Służbie Celnej, Dz.U. 2004, nr 156, poz. 1641 tekst jedn. ze zm.). W tym przypadku słusznie wskazano, że rozwiązanie stosunku służbowego w takim trybie nie może zostać uznane za równoznaczne z uznaniem winy funkcjonariusza, dopóki nie zapadnie prawomocne orzeczenie sądu karnego, stwierdzające, że bezrobotny dopuścił się zarzucanego mu czynu i w konsekwencji spowodował rozwiązanie stosunku służbowego bez wypowiedzenia ze swej winy. Trafnie przy tym podniesiono, że podmiot podejmujący decyzję o zwolnieniu funkcjonariusza nie bada w ogóle jego winy, opiera się wyłącznie na informacji o wniesieniu aktu oskarżenia. Jak słusznie zauważono, o ile cele społeczne, fiskalne oraz prestiż służby i walka z patologiami uzasadniają zwolnienie ze służby funkcjonariusza przed stwierdzeniem jego winy, o tyle nie można pozbawiać go prawa do zasiłku dla bezrobotnych na podstawie przepisu odnoszącego się do zawinionego rozwiązania stosunku służbowego (wyrok Wojewódzkiego Sądu Administracyjnego w Lublinie z dnia 28 września 2006 roku, III SA/Lu 282/06, LEX nr 910284).

Dość powszechną, jednak niezgodną z prawem praktyką jest również kwalifikowanie, jako uzasadniającego zastosowanie okresu karencji na podstawie art. 75 ust. 1 pkt 3 ustawy o promocji zatrudnienia, rozwiązania stosunku służbowego, zawieszonego (na podstawie art. 26 pkt 13 ustawy z dnia 24 lipca 1999 roku o Służbie Celnej, a także na podstawie art. 41 ust. 2 pkt 9 ustawy o Policji) z powodu wszczęcia postępowania karnego o umyślne przestępstwo ścigane z oskarżenia publicznego. W tych przypadkach w ocenie sądu bezpośrednią przyczyną rozwiązania stosunku służbowego jest upływ wskazanego w przepisie okresu zawieszenia (wyrok Wojewódzkiego Sądu Administracyjnego w Warszawie z dnia 3 sierpnia 2016 roku, II SA/Wa 328/16, LEX nr 2113521), na co może mieć wpływ w szczególności przedłużające się postępowanie karne, nie zaś samo wniesienie aktu oskarżenia czy prowadzenie postępowania karnego (wyrok Wojewódzkiego Sądu Administracyjnego w Białymstoku z dnia 12 października 2010 roku, II SA/Bk 514/10, LEX nr 752340; art. 105 pkt 10 ustawy o Służbie Celnej; wyrok Wojewódzkiego Sądu Administracyjnego w Rzeszowie z dnia 21 września 2010 roku, II SA/Rz 439/10, LEX nr 754589; wyrok Wojewódzkiego Sądu Administracyjnego w Rzeszowie z dnia 25 października 2010 roku, II SA/Rz 619/10, LEX nr 621287).

Uzupełniając katalog przypadków, w których błędnie utożsamiono przyczynę rozwiązania stosunku służbowego z zawinionym i niezwłocznym jego ustaniem, należy wskazać zwolnienie funkcjonariusza Policji ze względu na ważny interes służby (na podstawie art. 42 ust. 1 pkt 5 ustawy o Policji). Choć pojęcie „ważnego interesu służby” nie zostało w ustawie o Policji wyjaśnione, w praktyce słusznie przyjmuje się, że na podstawie tej przesłanki dokonuje się zwolnień funkcjonariuszy, którzy w ocenie przełożonych nie powinni z przyczyn pozamerytorycznych dalej pełnić służby. Owa przesłanka powinna być przy tym skonkretyzowana przez wskazanie okoliczności faktycznych występujących w sprawie składających się na taką ocenę. Nie powinno jednak budzić wątpliwości, że 
chodzi tu o dobro interesu służby, rozumianego jako interes społeczny. Dlatego nie można przyjąć, że rozwiązanie stosunku służbowego ze względu na ważny interes służby nastąpiło z winy skarżącego (wyrok Wojewódzkiego Sądu Administracyjnego w Warszawie z dnia 12 czerwca 2019 roku, II SA/Wa 2236/18, LEX nr 2866061).

Na zakończenie trzeba również przytoczyć przykład poprawnego zastosowania sankcji w postaci okresu karencji. W rozpatrywanym przypadku trafnie wskazano, że ustawa o Straży Granicznej nie zawiera regulacji, które można utożsamiać z zawinionym przez pracownika niezwłocznym rozwiązaniem stosunku pracy, o którym mowa w art. 52 k.p., ponieważ odnosi się do obligatoryjnego i fakultatywnego zwolnienia ze służby, a decyzja o zwolnieniu ze służby ma charakter konstytutywny. Jednak treść przepisu art. 45 ust. 2 pkt 10 tej ustawy można utożsamić $\mathrm{z}$ rozwiązaniem stosunku pracy $\mathrm{z}$ winy pracownika z powodu popełnienia przez niego w czasie trwania umowy o pracę przestępstwa, które uniemożliwia dalsze zatrudnianie go na zajmowanym stanowisku, jeżeli przestępstwo jest oczywiste (art. $52 \S 1$ pkt 2 k.p.). Przepis ten pozwala bowiem na zwolnienie ze służby funkcjonariusza w przypadku popełnienia przez niego czynu o znamionach przestępstwa albo przestępstwa skarbowego, jeżeli popełnienie czynu jest oczywiste i uniemożliwia pozostawanie w służbie (wyrok Wojewódzkiego Sądu Administracyjnego w Szczecinie z dnia 5 października 2017 roku, II SA/Sz 852/17, LEX nr 2390442).

\section{Podsumowanie}

Z przeprowadzonych analiz wyraźnie wynika potrzeba interwencji ustawodawcy w co najmniej kilku obszarach. Jak się wydaje, najbardziej istotną kwestią jest usystematyzowanie stosowanej w art. 71 nomenklatury i uregulowanie w sposób niebudzący wątpliwości znaczenia pojęć służby i stosunków służbowych, zwłaszcza że występują one jeszcze $\mathrm{w}$ innych przepisach ustawy o promocji zatrudnienia. Obecna regulacja nie ułatwia denotacji używanych przez ustawodawcę pojęć, a uzyskane w wyniku skomplikowanych zabiegów interpretacyjnych rezultaty nie są w pełni satysfakcjonujące, głównie ze względu na krzyżujące się zakresy znaczeniowe obu pojęć, utrudniające klarowne ustalenie zachodzącej między nimi relacji. W tym zakresie jako godny rozważenia wzór regulacyjny można powołać na przykład definicję stosunków służbowych sformułowaną na potrzeby ustawy systemowej (art. 8 ust. 15). Wprowadzenie tego rodzaju definicji do ustawy o promocji zatrudnienia ułatwiłoby niewątpliwie ustalenie, które okresy, jakiego rodzaju służby lub stosunków służbowych wpływają na prawo do zasiłku dla bezrobotnych.

Na potrzebę nowelizacji ustawy wskazuje również skrajnie rozbieżne orzecznictwo sądowe odnoszące się do długości stażu wymaganego do udowodnienia przez osoby zwalniane ze służby w formacjach uzbrojonych niewchodzących w skład Sił Zbrojnych, takich jak Policja, Straż Graniczna i Służba Ochrony Państwa. Chodziłoby przy tym o wyraźne rozstrzygnięcie, czy służbę tę można traktować jako równoznaczną z zasadniczą służbą wojskową - również na gruncie ustawy o promocji zatrudnienia - z konsekwencjami w postaci krótszego stażu warunkującego prawo do zasiłku dla bezrobotnych. 
Przeprowadzona analiza uwidoczniła również potrzebę dostosowania nomenklatury dotyczącej rozwiązania stosunku służbowego w regulacji odnoszącej się do okresów karencyjnych do specyfiki tego rodzaju zatrudnienia. Niestety nie jest to zadanie łatwe, zważywszy na różnice terminologiczne i konstrukcyjne w poszczególnych pragmatykach służbowych, wynikające nie tylko z konieczności uwzględnienia specyfiki działania konkretnej formacji, ale również z tego, że powstawały one w różnym czasie, bazując na zmieniających się koncepcjach. Mając tego świadomość, należy jednak wyrazić przekonanie, że pozostawienie zasygnalizowanych w opracowaniu rozwiązań prawnych w niezmienionym kształcie, mimo wysiłków interpretacyjnych czynionych w judykaturze, będzie nadal powodować niepotrzebne przeszkody dla byłych funkcjonariuszy i żołnierzy $\mathrm{w}$ realizacji prawa do zabezpieczenia społecznego na wypadek braku pracy.

\section{Bibliografia}

Antonów K. (2004) Zakres podmiotowy obowiązkowego ubezpieczenia emerytalnego [w:] T. Bińczycka-Majewska (red.), Konstrukcje prawa emerytalnego, Kraków.

Góral Z. (2016) Komentarz do Rozdziału 15 [w:] Z. Góral (red.), Ustawa o promocji zatrudnienia i instytucjach rynku pracy. Komentarz, wyd. 2, Warszawa.

Jaworska K. (2016) Socjalne traktowanie bezrobocia, Olsztyn.

Mazurczak-Jasińska E. (2015) Ustanie niepracowniczego stosunku zatrudnienia typu administracyjnoprawnego funkcjonariuszy i żotnierzy zawodowych [w:] K.W. Baran (red.), System prawa pracy, t. 7: Zatrudnienie niepracownicze, Warszawa.

Nowak D. (2019) Stużba wojskowa jako element powszechnego obowiąku obrony ojczyzny, „Wiedza Obronna”, t. 268, nr 3.

Paluszkiewicz M. (2018) Prawo do zasitku dla bezrobotnych [w:] K.W. Baran (red.), System prawa pracy, t. 8: Prawo rynku pracy, Warszawa.

\section{Orzecznictwo}

Wyrok Naczelnego Sądu Administracyjnego (do 31 grudnia 2003 roku) w Białymstoku z dnia 20 czerwca 2002 roku, SA/Bk 209/02, LEX nr 79657.

Wyrok Naczelnego Sądu Administracyjnego z dnia 17 lutego 2009 roku, I OSK 389/09, LEX nr 522425.

Wyrok Sądu Najwyższego z dnia 18 października 2013 roku, I UK 125/13, OSNP 2014/9/137. Wyrok Sądu Najwyższego z dnia 19 stycznia 2017 roku, I UK 121/16, LEX nr 2216098.

Wyrok Sądu Okręgowego w Krakowie z dnia 7 kwietnia 2014 roku, VII Ua 110/13, LEX nr 2440903. Wyrok Sądu Okręgowego Warszawa-Praga w Warszawie z dnia 28 marca 2019 roku, VII Ua 2/19, LEX nr 2675893.

Wyrok Wojewódzkiego Sądu Administracyjnego w Białymstoku z dnia 12 października 2010 roku, II SA/Bk 514/10, LEX nr 752340.

Wyrok Wojewódzkiego Sądu Administracyjnego w Bydgoszczy z dnia 2 października 2018 roku, II SA/Bd 870/18, LEX nr 2579468. 
Wyrok Wojewódzkiego Sądu Administracyjnego w Gdańsku z dnia 25 lipca 2019 roku, III SA/Gd 352/19, LEX nr 2704720.

Wyrok Wojewódzkiego Sądu Administracyjnego w Krakowie z dnia 20 czerwca 2012 roku, III SA/Kr 1547/11, LEX nr 1246005.

Wyrok Wojewódzkiego Sądu Administracyjnego w Krakowie z dnia 27 lutego 2013 roku, III SA/Kr 1354/12, LEX nr 1278042.

Wyrok Wojewódzkiego Sądu Administracyjnego w Krakowie z dnia 9 października 2018 roku, III SA/Kr 779/18, LEX nr 2579435.

Wyrok Wojewódzkiego Sądu Administracyjnego w Lublinie z dnia 28 września 2006 roku, III SA/Lu 282/06, LEX nr 910284.

Wyrok Wojewódzkiego Sądu Administracyjnego w Lublinie z dnia 7 grudnia 2006 roku, III SA/Lu 437/06, LEX nr 327463.

Wyrok Wojewódzkiego Sądu Administracyjnego w Łodzi z dnia 29 października 2013 roku, III SA/Łd 938/13, LEX nr 1504317.

Wyrok Wojewódzkiego Sądu Administracyjnego w Poznaniu z dnia 4 października 2007 roku, IV SA/Po 125/07, LEX nr 982803.

Wyrok Wojewódzkiego Sądu Administracyjnego w Rzeszowie z dnia 21 września 2010 roku, II SA/Rz 439/10, LEX nr 754589.

Wyrok Wojewódzkiego Sądu Administracyjnego w Rzeszowie z dnia 25 października 2010 roku, II SA/Rz 619/10, LEX nr 621287.

Wyrok Wojewódzkiego Sądu Administracyjnego w Szczecinie z dnia 19 grudnia 2007 roku, II SA/Sz 734/07, LEX nr 470204.

Wyrok Wojewódzkiego Sądu Administracyjnego w Szczecinie z dnia 5 października 2017 roku, II SA/Sz 852/17, LEX nr 2390442.

Wyrok Wojewódzkiego Sądu Administracyjnego w Warszawie z dnia 22 sierpnia 2006 roku, II SA/Wa 938/06, LEX nr 282423.

Wyrok Wojewódzkiego Sądu Administracyjnego w Warszawie z dnia 3 sierpnia 2016 roku, II SA/Wa 328/16, LEX nr 2113521.

Wyrok Wojewódzkiego Sądu Administracyjnego w Warszawie z dnia 12 czerwca 2019 roku, II SA/Wa 2236/18, LEX nr 2866061.

Wyrok Wojewódzkiego Sądu Administracyjnego we Wrocławiu z dnia 17 sierpnia 2017 roku, IV SA/Wr 182/17, LEX nr 2349712.

\section{Akty prawa krajowego}

Konstytucja Rzeczypospolitej Polskiej z dnia 2 kwietnia 1997 roku, Dz.U. 1997, nr 78, poz. 483 z dnia 16 lipca 1997 roku.

Rozporządzenie Ministra Rodziny Pracy i Polityki Społecznej z dnia 14 kwietnia 2020 roku w sprawie rejestracji bezrobotnych i poszukujących pracy, Dz.U. 2020, poz. 667.

Rozporządzenie Ministra Spraw Wewnętrznych z dnia 14 maja 2013 roku w sprawie szczegółowych praw i obowiązków oraz przebiegu służby policjantów, Dz.U. 2020, poz. 1113 tekst jedn. 
Rozporządzenie Rady Ministrów z dnia 5 listopada 1992 roku w sprawie szczególnych uprawnień żołnierzy i osób spełniających zastępczo obowiązek służby wojskowej oraz członków ich rodzin, Dz.U. 1992, nr 85, poz. 430 ze zm.

Rozporządzenie Rady Ministrów z dnia 3 lutego 2011 roku w sprawie określenia formacji uzbrojonych niewchodzących w skład Sił Zbrojnych, w których pełnienie służby jest równoznaczne ze spełnieniem obowiązku zasadniczej służby wojskowej, Dz.U. 2011, nr 42, poz. 215.

Ustawa z dnia 21 listopada 1967 roku o powszechnym obowiązku obrony RP, Dz.U. 2019, poz. 1541 tekst jedn. ze zm.

Ustawa z dnia 26 czerwca 1974 roku - Kodeks pracy, Dz.U. 2020, poz. 1320 tekst jedn.

Ustawa z dnia 6 kwietnia 1990 roku o Policji, Dz.U. 2020, poz. 360 tekst jedn. ze zm.

Ustawa z dnia 12 października 1990 roku o Straży Granicznej, Dz.U. 2020, poz. 305 tekst jedn. ze zm.

Ustawa z dnia 24 sierpnia 1991 roku o Państwowej Straży Pożarnej, Dz.U. 2020, poz. 1123 tekst jedn. ze zm.

Ustawa z dnia 10 grudnia 1993 roku o zaopatrzeniu emerytalnym żołnierzy zawodowych oraz ich rodzin, Dz.U. 2020, poz. 586 tekst jedn. ze zm.

Ustawa z dnia 18 lutego 1994 roku o zaopatrzeniu emerytalnym funkcjonariuszy Policji, Agencji Bezpieczeństwa Wewnętrznego, Agencji Wywiadu, Służby Kontrwywiadu Wojskowego, Służby Wywiadu Wojskowego, Centralnego Biura Antykorupcyjnego, Straży Granicznej, Straży Marszałkowskiej, Służby Ochrony Państwa, Państwowej Straży Pożarnej, Służby Celno-Skarbowej i Służby Więziennej oraz ich rodzin, Dz.U. 2020, poz. 723 tekst jedn.

Ustawa z dnia 13 października 1998 roku o systemie ubezpieczeń społecznych, Dz.U. 2021, poz. 423 tekst jedn. ze zm.

Ustawa z dnia 25 czerwca 1999 roku o świadczeniach pieniężnych z ubezpieczenia społecznego w razie choroby i macierzyństwa, Dz.U. 2021, poz. 1133 tekst jedn.

Ustawa z dnia 24 lipca 1999 roku o Służbie Celnej, Dz.U. 2004, nr 156, poz. 1641 tekst jedn. ze zm.

Ustawa z dnia 24 maja 2002 roku o Agencji Bezpieczeństwa Wewnętrznego oraz Agencji Wywiadu, Dz.U. 2020, poz. 27 tekst jedn. ze zm.

Ustawa z dnia 11 września 2003 roku o służbie wojskowej żołnierzy zawodowych, Dz.U. 2021, poz. 1131 tekst jedn. ze zm.

Ustawa z dnia 28 listopada 2003 roku o służbie zastępczej, Dz.U. 2018, poz. 855 tekst jedn.

Ustawa z dnia 20 kwietnia 2004 roku o promocji zatrudnienia i instytucjach rynku pracy, Dz.U. 2021, poz. 1100 tekst jedn. ze zm.

Ustawa z dnia 9 czerwca 2006 roku o Centralnym Biurze Antykorupcyjnym, Dz.U. 2019, poz. 1921 tekst jedn. ze zm.

Ustawa z dnia 9 czerwca 2006 roku o służbie funkcjonariuszy Służby Kontrwywiadu Wojskowego oraz Służby Wywiadu Wojskowego, Dz.U. 2020, poz. 1221 tekst jedn. ze zm.

Ustawa z dnia 27 sierpnia 2009 roku o Służbie Celnej, Dz.U. 2009, nr 168, poz. 1323 ze zm.

Ustawa z dnia 27 sierpnia 2009 roku o zmianie ustawy o powszechnym obowiązku obrony RP oraz zmianie niektórych innych ustaw, Dz.U. 2009, nr 161, poz. 1278. 
Ustawa z dnia 9 kwietnia 2010 roku o Służbie Więziennej, Dz.U. 2020, poz. 848 tekst jedn. ze zm. Ustawa z dnia 14 marca 2014 roku o zmianie ustawy o promocji zatrudnienia i instytucjach rynku pracy, Dz.U. 2014, poz. 598.

Ustawa z dnia 16 listopada 2016 roku o Krajowej Administracji Skarbowej, Dz.U. 2020, poz. 505 tekst jedn. ze zm.

Ustawa z dnia 11 maja 2017 roku o zmianie ustawy o zaopatrzeniu emerytalnym funkcjonariuszy Policji, Agencji Bezpieczeństwa Wewnętrznego, Agencji Wywiadu, Służby Kontrwywiadu Wojskowego, Służby Wywiadu Wojskowego, Centralnego Biura Antykorupcyjnego, Straży Granicznej, Biura Ochrony Rządu, Państwowej Straży Pożarnej i Służby Więziennej oraz ich rodzin oraz niektórych innych ustaw, Dz.U. 2017, poz. 1321.

Ustawa z dnia 8 grudnia 2017 roku o Służbie Ochrony Państwa, Dz.U. 2020, poz. 384 tekst jedn. ze zm.

Ustawa z dnia 26 stycznia 2018 roku o Straży Marszałkowskiej, Dz.U. 2019, poz. 1940 tekst jedn. ze zm. 